\title{
Steroidogenesis in the NCI-H295 Cell Line Model is Strongly Affected By Culture Conditions and Substrain
}

\author{
Authors \\ Max Kurlbaum, 2, Silviu Sbiera', Sabine Kendl1, 2, Martin Fassnacht ${ }^{1,2,3}$, Matthias Kroiss ${ }^{1,3}$
}

Affiliations

1 Department of Internal Medicine I, Division of Endocrinology and Diabetes, University of Würzburg, University Hospital Würzburg, Würzburg, Germany

2 University Hospital Würzburg, Central Laboratory, Würzburg, Germany

3 Comprehensive Cancer Center Mainfranken, University of Würzburg, Würzburg, Germany

\section{Key words}

Steroid hormones, glucocorticoids, androgens, adrenocortical carcinoma, cell culture

$\begin{array}{ll}\text { revised } & 16.01 .2020 \\ \text { received } & 21.08 .2019 \\ \text { accepted } & 23.01 .2020\end{array}$

Bibliography

DOI https://doi.org/10.1055/a-1105-6332

Published online: 29.4 .2020

Exp Clin Endocrinol Diabetes 2020; 128: 672-680

(c) J. A. Barth Verlag in Georg Thieme Verlag KG Stuttgart .

New York

ISSN 0947-7349

\section{Correspondence}

Matthias Kroiss, MD, PhD

University Hospital Würzburg, Department of Internal Medicine I, Division of Endocrinology and Diabetology Oberdürrbacher Str. 6

97080 Würzburg

\section{Germany}

Tel.: + 49-931-20139740, Fax: +49-931-2016039740

kroiss_m@ukw.de

Max Kurlbaum, PhD

University Hospital Würzburg, Department of Internal

Medicine I, Division of Endocrinology and Diabetology

Oberdürrbacher Str. 6

97080 Würzburg

Germany

Tel.: + 49-931-20139226, Fax: + 49-931-2016039740

kurlbaum_m1@ukw.de
Supplementary Material for this article is available online at http://doi.org/10.1055/a-1105-6332

\section{ABSTRACT}

Context NCl-H295 cells are the most widely used model for adrenal steroidogenesis and adrenocortical carcinoma and have been used for decades in laboratories worldwide. However, reported steroidogenic properties differ considerably.

Objective To evaluate heterogeneity of steroidogenesis among $\mathrm{NCl}-\mathrm{H} 295$ cell strains, clarify the influence of culture media and test response to inhibitors of steroidogenesis by using liquid chromatography tandem mass spectrometry (LCMS/MS).

Methods $\mathrm{NCl}-\mathrm{H} 295$ cells were obtained from two cell banks and cultivated in different media. An LC-MS/MS-based panel analysis of thirteen steroids was adapted for cell culture supernatant. Cells were treated with metyrapone, abiraterone and mitotane.

Results Mineralocorticoid synthesis was strongly affected by passaging as reflected by reduction of aldosterone secretion from $0.158 \pm 0.006$ to $0.017 \pm 0.001 \mu \mathrm{g} / 10^{6}$ cells $(p<0.05)$. Relevant differences were also found for cells from two vendors in terms of aldosterone secretion $(0.180 \pm 0.001$ vs. $0.09 \pm$ $0.002 \mu \mathrm{g} / 10^{6}$ cells, $\left.\mathrm{p}<0.05\right)$. Selection of medium strongly impacted on cortisol secretion with $>4$-fold difference (40.6 \pm 5.5 vs. $182.1 \pm 23 \mu \mathrm{g} / 10^{6}$ cells) and reflected differential activation of the glucocorticoid pathway. Exposure to abiraterone, metyrapone and mitotane resulted in characteristic steroidogenic profiles consistent with known mechanism of drug action with considerable differences in metabolites upstream of the blocked enzyme.

Conclusion We demonstrate that steroid hormone secretion in $\mathrm{NCl}-\mathrm{H} 295$ cells is strongly affected by the individual strain, passage and growing conditions. These factors should be taken into account in the evaluation of experiments analyzing steroid parameters directly or as surrogate parameters of cell viability. 


\section{Introduction}

Only few cell culture models of the adrenal cortex have been established to study molecular pathways in adrenocortical physiology and steroidogenesis and also to develop treatments of adrenocortical carcinoma (ACC).

ACC is a rare malignant disease $[1,2]$ which harbors a high risk of recurrence and metastatic spread even after complete resection [3-5]. The human $\mathrm{NCl}-\mathrm{H} 295$ cell line is the current "gold standard" for in vitro experiments in ACC research [6-11]. This cell line has also been of great value in understanding human adrenal physiology $[12,13]$ and toxicology of endocrine active environmental polluants [14-17]. Importantly rodent animal models do not fully reflect human properties of the adrenal cortex [18]. Only recently, Hantel et al [19] and Kiseljak-Vassilliades et al. [20] established new cell lines that were termed MUC-1 and CU-ACC1/CU-ACC2, respectively.

The initial $\mathrm{NCl}-\mathrm{H} 295$ cell line has been described to secrete predominantly androgens and androgen sulfates (dehydroepiandrosterone- epiandrosterone- and androsterone-sulfate). It was reported that growth and steroid production was 4-fold decreased in serum-free medium [21].

As derivatives of these $\mathrm{NCl}-\mathrm{H} 295$ cells, several substrains have been created by using alternative culture conditions. These were designated as $\mathrm{NCl}-\mathrm{H} 295$ "R" and grow as a monolayer (> Fig. 1). $\mathrm{NCl}-\mathrm{H} 295$ " $\mathrm{R}$ ”-S1 requires Nu-Serum type 1, NCl-H295 “ $\mathrm{R}$ "-S2 is cultivated in the presence of Ultroser ${ }^{\circledR}$ and $\mathrm{NCl}-\mathrm{H} 295$ "R"-S3 was established with Cosmic Calf serum [22]. A similar strategy was pursued to obtain a strain named $\mathrm{NCl}-\mathrm{H} 295$ " $A$ " by removing nonattached cells during passaging. In 2008 the cell lines "HAC 13/15" were established as monoclonal sub-strains from $\mathrm{NCl}-\mathrm{H} 295 \mathrm{R}$ cells [23].

$\mathrm{NCl}-\mathrm{H} 295$ cells that grow as monolayers exhibit different responses to hormonal stimulation. The initially described $\mathrm{NCl}-\mathrm{H} 295$ cells did not respond to ACTH-stimulation which is shared by the $\mathrm{NCl}-\mathrm{H} 295 \mathrm{~A}$ strain. $\mathrm{HAC} 13 / 15$ in turn are sensitive to stimulation with ACTH while conflicting data have been reported for $\mathrm{NCI}$ H295R cells [24-26]. On the other hand, preserved response of $\mathrm{NCl}-\mathrm{H} 295 \mathrm{R}$ cells to forskolin and the absence of ACTH-responsive-

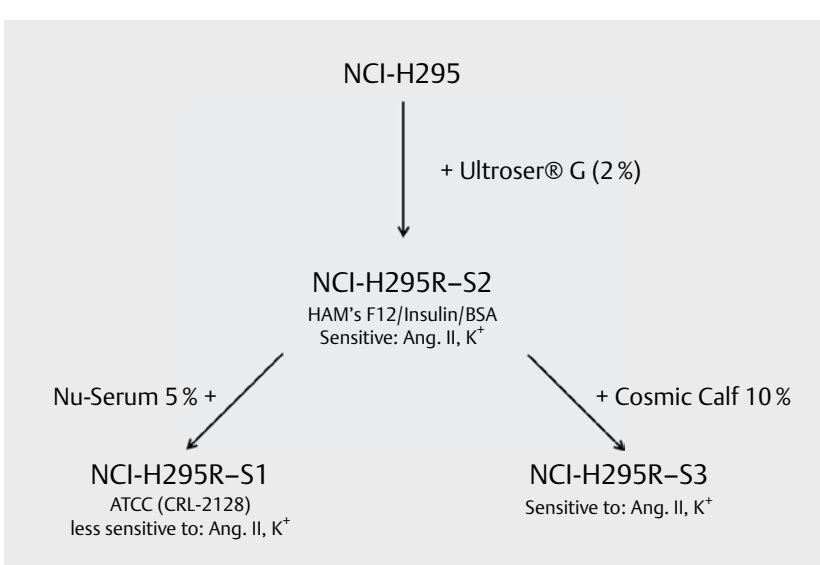

Fig. 1 Published sub-strains derived from the original NCl-H295 cells. NCl-H295 S1-3 sub-strains were established by cultivating NCl$\mathrm{H} 295$ cells over different periods and using various cell culture additives. Floating cells were removed periodically to select adherent cells. ness indicates a defective receptor signaling. Ang II is able to stimulate HAC 13/15 and $\mathrm{NCl}-\mathrm{H} 295 \mathrm{R}$ cells but does not lead to aldosterone secretion in $\mathrm{NCl}-\mathrm{H} 295 \mathrm{~A}$ and $\mathrm{NCl}-\mathrm{H} 295$ cells, respectively [27-30].

It is well known that selection induced by prolonged growing and culture conditions can lead to genetic, transcriptional and translational changes in cell lines and lead to the development of substrains in different laboratories. [31]. This fact is illustrated by data published by Samandari et al. who compared NCI-H295R with $\mathrm{NCl}-\mathrm{H} 295 \mathrm{~A}$ cells and found expression of $3 \beta$-hydroxysteroiddehydrogenase (HSD3B2), sulfonyltransferase and cytochrome b5 to be expressed at higher levels in NCl-H295A cells whereas higher 17, 20-lyase activity was present in NCl-H295R cells [26]. The observation of lower mRNA expression of 3 $\beta$-hydroxysteroid dehydrogenase in $\mathrm{NCl}-\mathrm{H} 295 \mathrm{R}$ cell lines underscored their observation of an androgen dominated pathway in steroid metabolism.

In summary these data suggest relevant differences in gene expression and phenotype of cell lines in this standard model for in vitro experiments. Published data are limited as to which extent experimental conditions, cell strains and passaging impact on steroid excretion of $\mathrm{NCl}-\mathrm{H} 295$ cells. Coming from discrepancies between results in our laboratory and the literature, we here used liquid chromatography mass spectrometry to address these questions by measurement of relevant steroid hormones and metabolites in $\mathrm{NCl}-\mathrm{H} 295$ cell culture supernatants in various experimental settings.

\section{Materials and Methods}

\section{Chemicals}

All buffers, chemicals, substances and solvents were purchased from Merck (Darmstadt, Germany) unless otherwise stated. DMEM/F-12, HEPES w/o phenol red, Gibco ${ }^{\text {TM }}$ Insulin-Transferrin-Selenium and ITS premix Corning ${ }^{\mathrm{TM}}$ were from Fisher Scientific (Schwerte, Germany), Corning Nu-Serum ${ }^{\mathrm{TM}}$ Growth Medium Supplement and Ultroser $\mathrm{G}^{\mathrm{TM}}$ were purchased from PALL ${ }^{\mathrm{TM}}$ (Hampshire, UK). Reagents, standards, controls and analytical HPLC-columns for mass spectrometry were obtained from Chromsystems ${ }^{\mathrm{TM}}$ Chemicals (Gräfelfing).

\section{Cell strains}

$\mathrm{NCl}-\mathrm{H} 295 \mathrm{R}$ cells were obtained from Cell Line Service (CLS, Eppelheim, Germany) and are designated in this study as " 0 " (passage 21) which was used as reference cell line. Consecutive passages " $A$ " (CLS, passage 37), “ $B$ ” (CLS, passage 55), "C" (CLS, passage 46) of these cells, and cells designated " $D$ ” (passage 16) received from ATCC (Wesel, Germany) and E (unknown passage, continuous use outside of our lab) were used. All these cells were grown as monolayers in F12 HAM-medium supplemented with $1 \mathrm{mg} / \mathrm{ml}$ insulin, $0.55 \mathrm{mg} / \mathrm{ml}$ transferrin, $0.67 \mu \mathrm{g} / \mathrm{ml}$ selenium, and $2.5 \%$ Corning Nu-Serum, which served as the reference medium in a humid atmosphere at $37^{\circ} \mathrm{C}$ and $5 \% \mathrm{CO}_{2}$. $\mathrm{NCl}-\mathrm{H} 295 \mathrm{~S}$ suspension cells from ATCC were grown in RPMI 1640 medium supplemented with $10 \%$ FCS, $1 \%$ Transferrin, $4 \mu \mathrm{g} / \mathrm{ml}, 0.04 \%$ Insulin.

Cells were authenticated by comparison of short-tandem-repeat (STR) profile with the online database of the German Collec- 
tion of Microorganisms and Cell Cultures GmbH (DSMZ, https:// www.dsmz.de/services/services-human-and-animal-cell-lines/authentication-of-human-cell-lines.html). Cells were cultivated for four days, supernatants were analyzed from parallel cultures every $24 \mathrm{~h}$ each for steroids by LC-MS/MS.

\section{Culture media}

$\mathrm{NCl}-\mathrm{H} 295 \mathrm{R}$ cell line (cell line "0") was grown in the medium described above (reference medium) in a humid atmosphere at $37^{\circ} \mathrm{C}$ and $5 \% \mathrm{CO}_{2}$.

To analyze the impact of culture media on steroidogenesis, cells were cultivated in medium 0 (DMEM/F12supplemented with $2.5 \%$

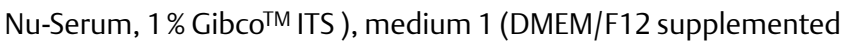

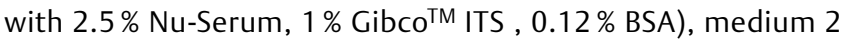
(DMEM/F12 supplemented with $2.5 \%$ Nu-Serum and $1 \%$ ITS Premix Corning ${ }^{\mathrm{TM}}$ ), medium 3 (DMEM/F12 supplemented with $2 \%$ Ultroser $\mathrm{G}$ and $1 \%$ Gibco $^{\mathrm{TM}} \mathrm{ITS}$ ) and medium 4 (DMEM/F12 supplemented

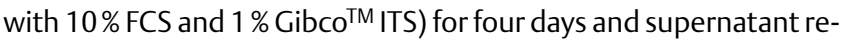
moved and analyzed by LC-MS/MS as described above. On day $0,10^{6}$ cells from one flask were distributed into two different well plates as biological duplicates. Every $24 \mathrm{~h}, 500 \mu \mathrm{l}$ from a total volume of $1 \mathrm{ml}$ medium was removed for analysis and an equal amount of fresh medium added. Every day cells were counted and the absolute amount of steroids normalized to cell count. (Countess II FL Automated Cell Thermo Fisher Scientific, Schwerte, Germany) (• Table 1S-5S).

\section{Drug treatment}

Consecutive passages $2\left(\mathrm{ATCC}_{2}\right)$ and $4\left(\mathrm{ATCC}_{3}\right)$ of cell lines $\mathrm{NCl}$ H295R (initial passage 9, ATCC 1 ) from ATCC and consecutive passages $12\left(\mathrm{CLS}_{1}\right), 14\left(\mathrm{CLS}_{2}\right), 17\left(\mathrm{CLS}_{3}\right), 74\left(\mathrm{CLS}_{4}\right), 77\left(\mathrm{CLS}_{5}\right)$ and 80 $\left(\mathrm{CLS}_{6}\right)$ of cell line $\mathrm{NCl}-\mathrm{H} 295 \mathrm{R}$ (initial passage 21) from CLS and consecutive passages of $\mathrm{NCl}-\mathrm{H} 295 \mathrm{~S}$ suspension cells $\left(\mathrm{CLS}_{7}, \mathrm{CLS}_{8}, \mathrm{CLS}_{9}\right)$ were treated with abiraterone $(1 \mu \mathrm{M})$, metyrapone $(0.5 \mu \mathrm{M})$ or mitotane $(10 \mu \mathrm{M})$ after cultivation [9] for $48 \mathrm{~h}$ in biological triplicates.

\section{Steroid hormone profiling}

For quantification of the 13 steroid hormones ( $\mathbf{F i g}$. 2 ) aldosterone, cortisone corticosterone, progesterone, cortisol, 11-deoxycortisol, $17 \alpha-\mathrm{OH}$-progesterone (17 $\alpha$-OHP), dehydroepiandrosterone -sulfate (DHEAS), testosterone, androstenedione, dehydroandrosterone (DHEA), dihydrotestosterone (DHT) and estradiol, we used the "Mass Chrom steroids ${ }^{\circledR}$ " assay (Chromsystems, Gräfelfing) which was validated for cell culture supernatants (see supplementary methods). Samples were treated according to the manufacturer's instructions. Briefly, $500 \mu$ l cell culture supernatant were subjected to off-line solid -phase extraction in 96 well plates. After a cleaning and concentration step $15 \mu$ of each sample were injected into an Agilent 1290 U-HPLC coupled to a QTRAP 6500 + (Sciex, Toronto) tandem mass spectrometer. Measurements were performed in ESI + mode except for aldosterone and DHEAS (ESI-). Stable isotope standards were used for all analytes and two MRM transitions (qualifier/quantifier) were established. Quantification was performed by 6 -point calibration curve ( $1 / x$ weighting). Correctness of measurements was confirmed by three quality control level running before and after each batch and periodic participating in external ring trials and inter-laboratory comparisons. Data were processed with Analyst ${ }^{\circledR}$ 1.6.3 Software. Results of the validation process in cell culture medium are supplied in Supplementary Methods.

\section{Statistical analysis}

All graphs, heat maps, figures and statistical analysis were created with Graph Pad Prism ${ }^{\circledR}$ 7.00, 2016 (Graph Pad Software Inc., San Diego, CA, USA). Mean \pm SD are provided. For comparison of means one-way ANOVA with Sidak's multiple comparisons Test was used. $p<0.05$ was considered to be statistically significant.

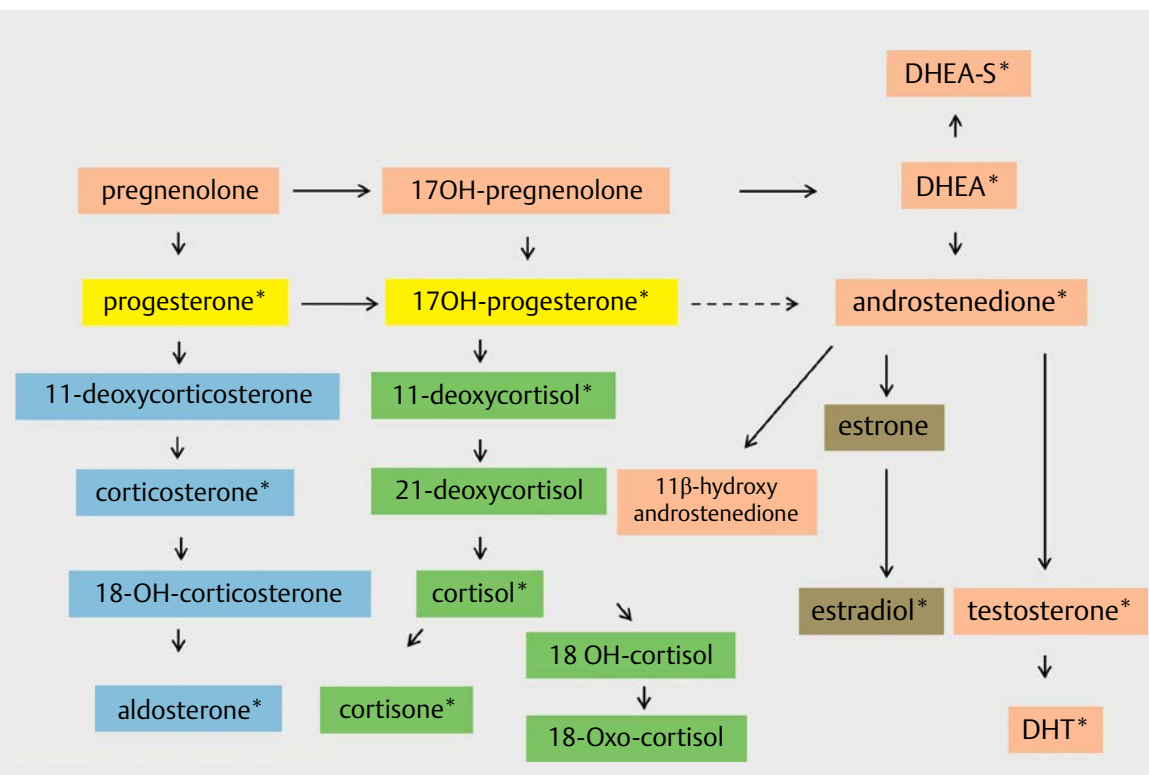

- Fig. 2 Metabolism and synthesis of steroid hormones in adrenal cells. Color coding is yellow for preliminary steps in glucocorticoid synthesis, green for glucocorticoids and precursors, blue for mineralocorticoids, orange for androgens and brown for estrogens. Asterisks indicate steroid hormones quantified by LC-MS/MS in this study (after Krone et al.[38]) 


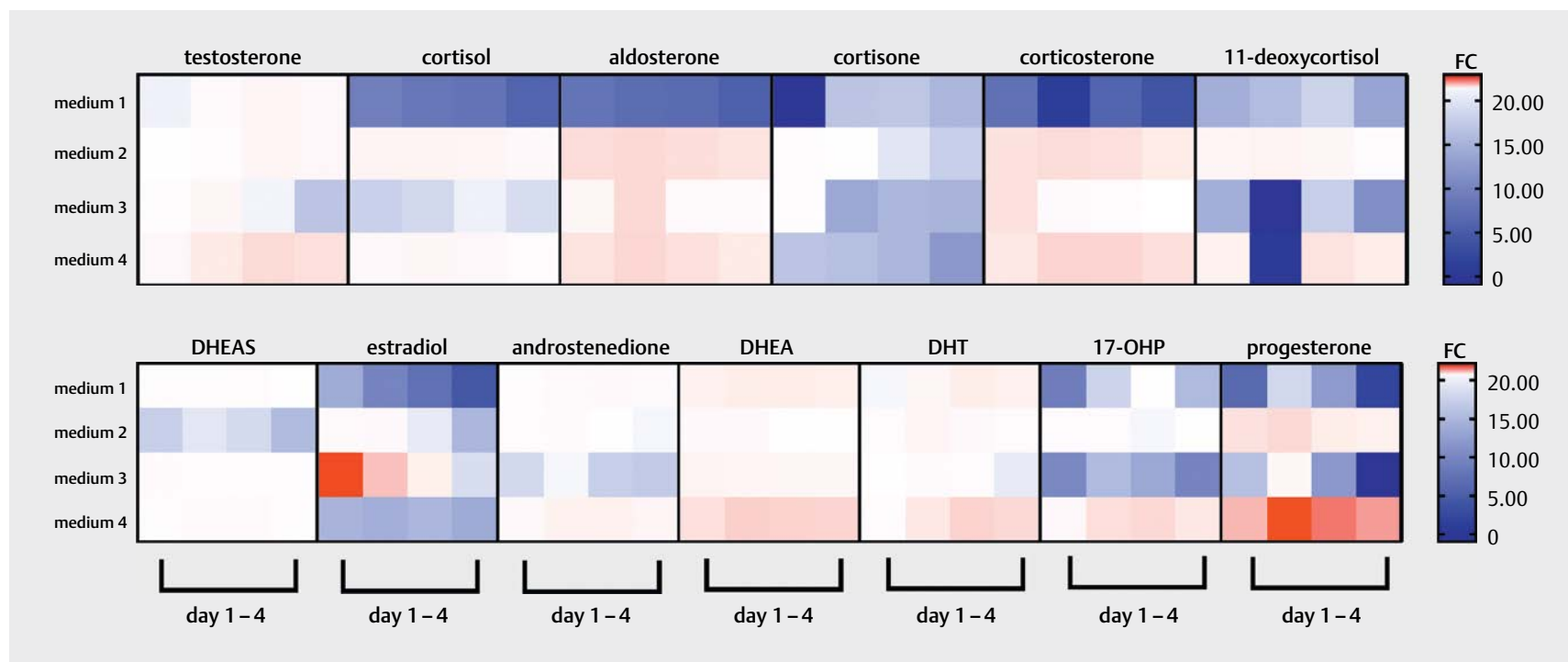

- Fig. 3 Steroid patterns in NCI-H295R cells illustrate heterogeneity in hormone excretion depending on composition of cell culture media. Heat map analysis of LC-MS/MS data. The columns represent time and the rows different media $(\mathbf{1}, \mathbf{2}, \mathbf{3}, \mathbf{4})$ in relation to standard medium used. Values are mean of biological duplicates. FC (fold change)

\section{Results}

\section{Impact of cell culture media on steroidogenesis}

To determine the impact of cell culture media on steroidogenesis of $\mathrm{NCl}-\mathrm{H} 295 \mathrm{R}$ cells, we used the cell line 0 and media $1-4$, which had all been previously described. In culture medium 2 ( $>$ Fig. 3), we detected $0.19 \pm 0.001 \mu \mathrm{g} / 10^{6}$ cells estradiol on day 1 , which increased during cultivation. Medium 3 contained approximately $8.1 \mu \mathrm{g} / \mathrm{l}$ estradiol, while in other media estradiol content was lower than $93 \mathrm{ng} / \mathrm{l}$. Steroid and hormone level of cell free media can be found in supplemental $>$ Table 6 S. When looking at mineralocorticoid secretion, aldosterone differed between media up to ten fold (medium 1 vs. medium 4 ) on day $3\left(0.06 \pm 0.01 \mathrm{vs} .0 .55 \pm 0.02 \mu \mathrm{g} / 10^{6}\right.$ cells, $\mathrm{p}<0.05)$. DHEA secretion differed by a factor of three between medium 3 and 4 on day $2\left(4.89 \pm 0.68\right.$ vs. $13.45 \pm 0.66 \mu \mathrm{g} / 10^{6}$ cells, $\mathrm{p}<0.05)$. Progesterone clearly decreased by $75 \%$ from day 2 to day 4 in medium 4 while $17 \alpha-\mathrm{OHP}, 11$-deoxycortisol, cortisol, cortisone and testosterone increased, reflecting a predominant steroid metabolism pathway by CYP21A2, 17A1 and 11B1. Consistently, corticosterone decreased clearly from day 2 to day 4 just as aldosterone by $30 \%$. Overall, medium 1 led to a decrease of the relative amount of glucocorticoids while, in medium 4 all steroids except cortisone and estradiol were present at higher concentration in relation to reference medium.

\section{Impact of cell line supplier and passage on steroid secretion}

By using culture medium 0 as a reference, we next investigated the impact of passaging and cell line provider in terms of secreted steroid metabolome ( $\vee$ Fig. 4 ).

Between two passages of a single $\mathrm{NCl}-\mathrm{H} 295 \mathrm{R}$ cell line (Cell Line Service) in our laboratory (A vs. B) aldosterone was found to be $0.316 \pm 0.02 \mu \mathrm{g} / 10^{6}$ and $0.158 \pm 0.006 \mu \mathrm{g} / 10^{6}$ cells $(\mathrm{p}<0.05)$ on day 3, 11-deoxycortisol differed twofold (131.3 \pm 10.5 vs. $59.2 \pm$
$2.25 \mu \mathrm{g} / 10^{6}$ cells, $\left.\mathrm{p}<0.05\right)$ and $17 \alpha-$ OHP almost two fold $(10.5 \pm$ 0.51 vs. $6.3 \pm 0.16 \mu \mathrm{g} / 10^{6}$ cells, $p<0.05$ ), respectively. By comparison, cells purchased from ATCC (D) showed predominant androgen secretion compared to $C L S$ cells $(A / B / C)$ as reflected by twice as high secretion of DHEA $\left(6.9 \pm 5\right.$ vs. $3.3 \pm 0.1 \mu \mathrm{g} / 10^{6}$ cells, $\mathrm{p}<0.05)$, three times more testosterone (15.9 \pm 0.51 vs. $5.2 \pm$ $0.29 \mathrm{ng} / 10^{6}$ cells, $\left.\mathrm{p}<0.05\right)$ and more than double dihydrotestosterone $\left(0.68 \pm 0.03\right.$ vs. $0.28 \pm 0.02 \mu \mathrm{g} / 10^{6}$ cells, $\left.p<0.05\right)$.

Throughout the whole test period, CLS cells (e.g. B) secreted up to three-fold more estradiol compared to ATCC (D) cells ( $148 \pm 2.63$ vs. $60 \pm 1.68 \mathrm{ng} / 10^{6}$ cells on day one, $\left.\mathrm{p}<0.05\right)$ A significant increase over time in estradiol concentration was found in supernatants from cell culture A, B and C (all CLS) in comparison to cell line E with constant low secretion. A comparable trend was found for testosterone where cell line D (ATCC) showed three times higher concentration on day 4 compared to day $1\left(5.3 \pm 0.08 \mathrm{vs} .17 .7 \pm 0.71 \mathrm{ng} / 10^{6}\right.$ cells, $\mathrm{p}<0.05)$.

Cell line E produced a remarkably lower amount of steroids compared to all other cell lines and passages but with a preponderance of estradiol and $17 \alpha-$ OHP ( $>$ Fig. 4).

To show the differences in relative amount and time course of steroid hormone secretion more clearly, we here consider cell lines $A$ and $D$ in more detail ( $>$ Fig. 5). Whereas in cell line $D$ secretion of most hormones increased continuously over cultivation time, the concentration of androstenedione reached a plateau after one day of growing in both cell lines (55.6 \pm 025 vs. $87.4 \pm 0.06 \mathrm{ng} / 10^{6}$ cells, $\mathrm{p}<0.05)$. The absolute quantities of steroid hormones differed markedly. Thus, on day 3 cell line $D$ reached a maximum $17 \alpha-O H P$ concentration of $26.8 \pm 0.79 \mathrm{ng} / 10^{6}$ cells while less than half $\left(10.5 \pm 0.51 \mathrm{ng} / 10^{6}\right.$ cells) was found in CLS cells on the same day. Progesterone was detected at higher concentrations early during cultivation which then decreased over four days to less than $15 \%$ of baseline level. 


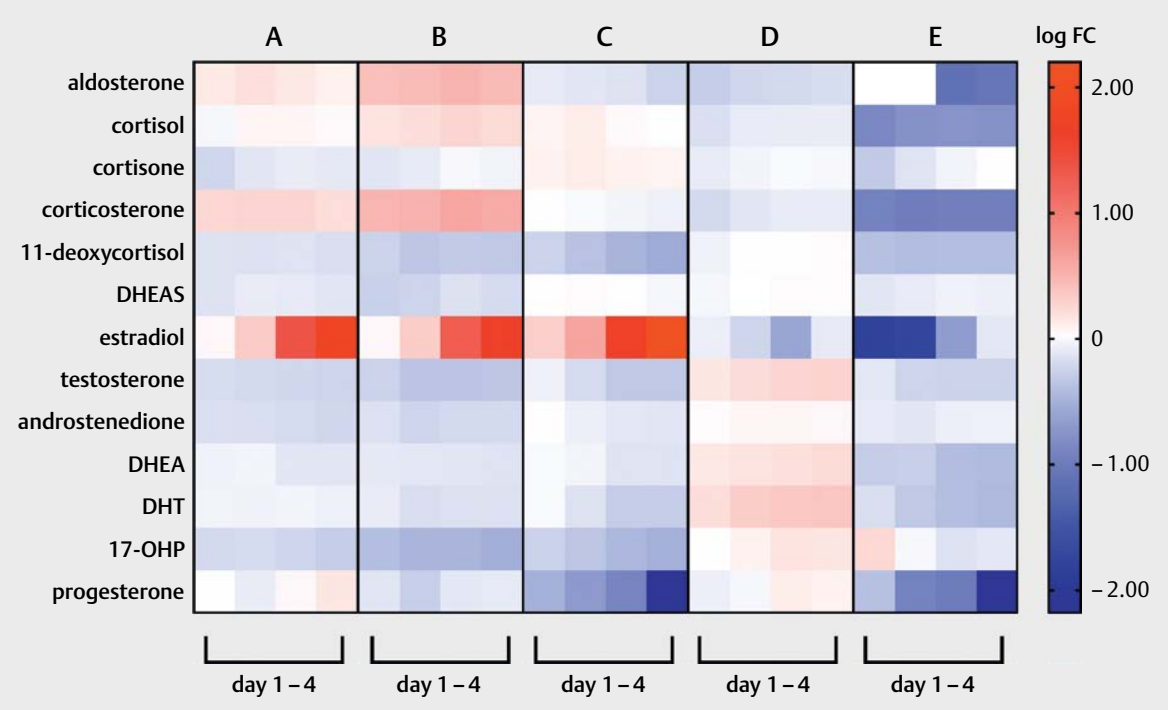

-Fig. 4 Steroid hormone profiles in cell culture supernatants from NCI-H295R cells purchased from the CLS (cell lines A, B, C, E) or ATCC (D) at various passages. CLS cell line at passage 21 (designated as " 0 ", not shown) at corresponding time points served as reference. The columns represent cultivation time and the rows the analyzed steroids by liquid chromatography mass spectrometry. $\log _{10}$ fold changes relative to cell number of $\mathrm{NCl}-\mathrm{H} 295 \mathrm{R}$ cells (CLS, substrain S1, passage 21) are displayed with blue indicating decrease, red indicating increase. A (NCI-H295R cells CLS passage 37), B (NCl-H295R cells CLS passage 55), C (NCI-H295R cells CLS passage 46), D (NCI-H295R cells ATCC passage 16), E (NCI-H295R cells CLS external laboratory). Values are the mean of biological duplicates. FC (fold change)
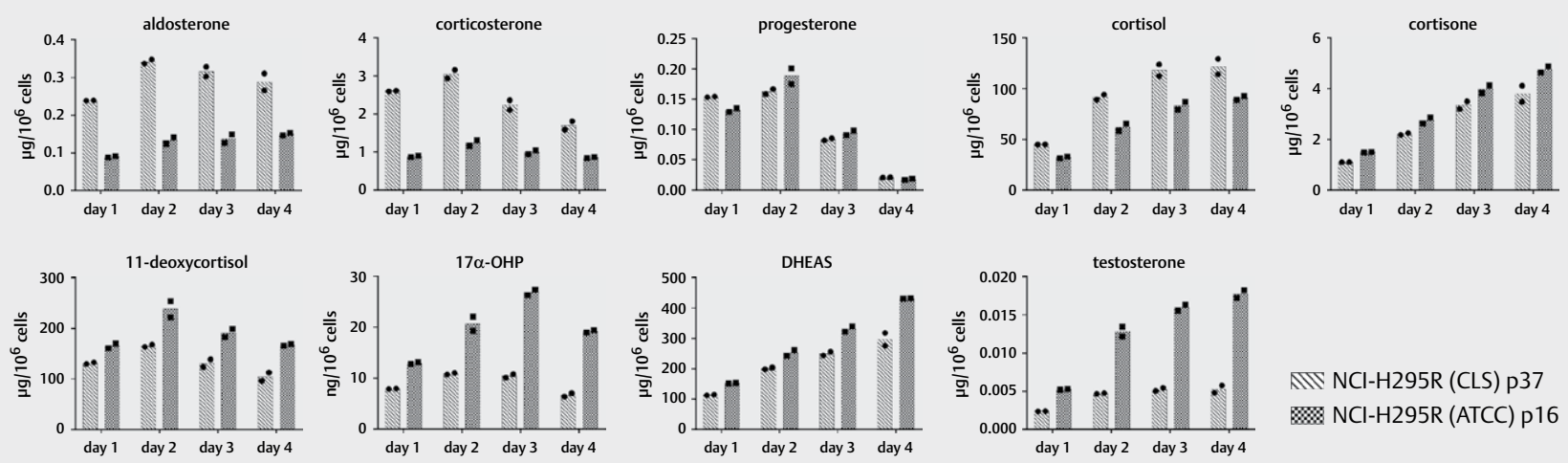

III NCI-H295R (CLS) p37
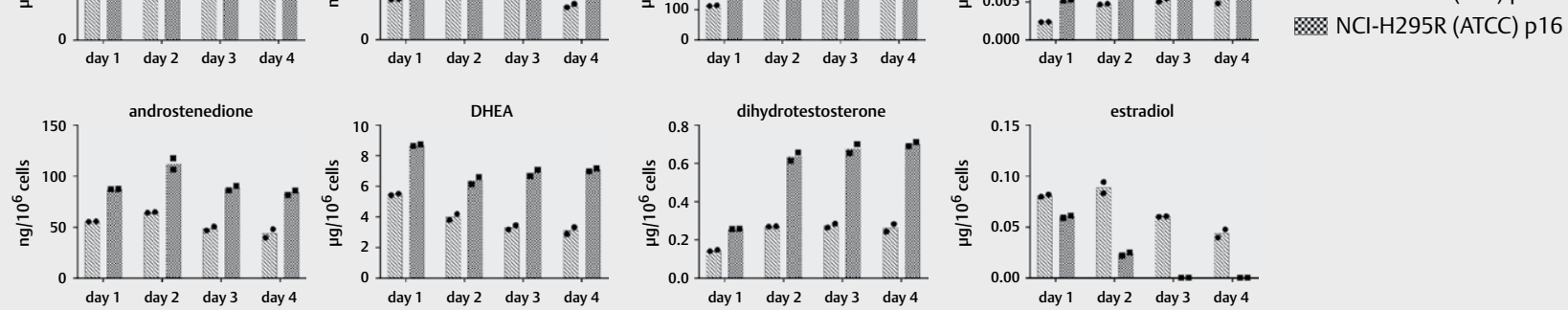

-Fig. 5 Steroid hormone excretion profile in NCI-H295 R cells from different providers. Quantity of 13 steroid hormones (aldosterone, corticosterone, progesterone, cortisol, cortisone, 11-deoxycortisol, $17 \alpha-\mathrm{OH}$-progesterone (17 $\alpha$-OHP), dehydroepiandrosterone -sulfate (DHEAs), testosterone, androstenedione, dehydroepiandrosterone (DHEA), dihydrotestosterone and estradiol) was determined in cell culture supernatants by LC-MS/MS normalized to cell count. Values are the mean of biological duplicates which are indicated individually.

Over time, amounts of progesterone, corticosterone and aldosterone decreased in cell line $A$ whereas conversely we observed an increase of dihydrotestosterone $\left(0.142 \pm 0.004 \mu \mathrm{g} / 10^{6}\right.$ on day $1 \mathrm{vs}$. $0.265 \pm 0.028 \mu \mathrm{g} / 10^{6}$ cells on day 4 , n. s.), testosterone $(0.024 \pm$ $0.0003 \mu \mathrm{g} / 10^{6}$ on day 1 vs. $0.053 \pm 0.0069 \mu \mathrm{g} / 10^{6}$ cells on day 4 , $\mathrm{p}<0.05)$, cortisol $\left(45.1 \pm 0.07 \mu \mathrm{g} / 10^{6}\right.$ on day 1 vs. $121.8 \pm 10.7 \mu \mathrm{g} / 10^{6}$ cells on day $4, p<0.05)$, and cortisone $\left(1.16 \pm 0.001 \mu \mathrm{g} / 10^{6}\right.$ on day 1 vs $3.80 \pm 0.44 \mu \mathrm{g} / 10^{6}$ cells on day $4, \mathrm{p}<0.05$ ) as a marker of predominant metabolism of precursors by CYP17A 1 and CYP11B1 to androgens and glucocorticoids under the selected conditions.

Differences in the ratios of cortisol and aldosterone between cell lines illustrate heterogeneity in preference of $17 \alpha$-hydroxylase 

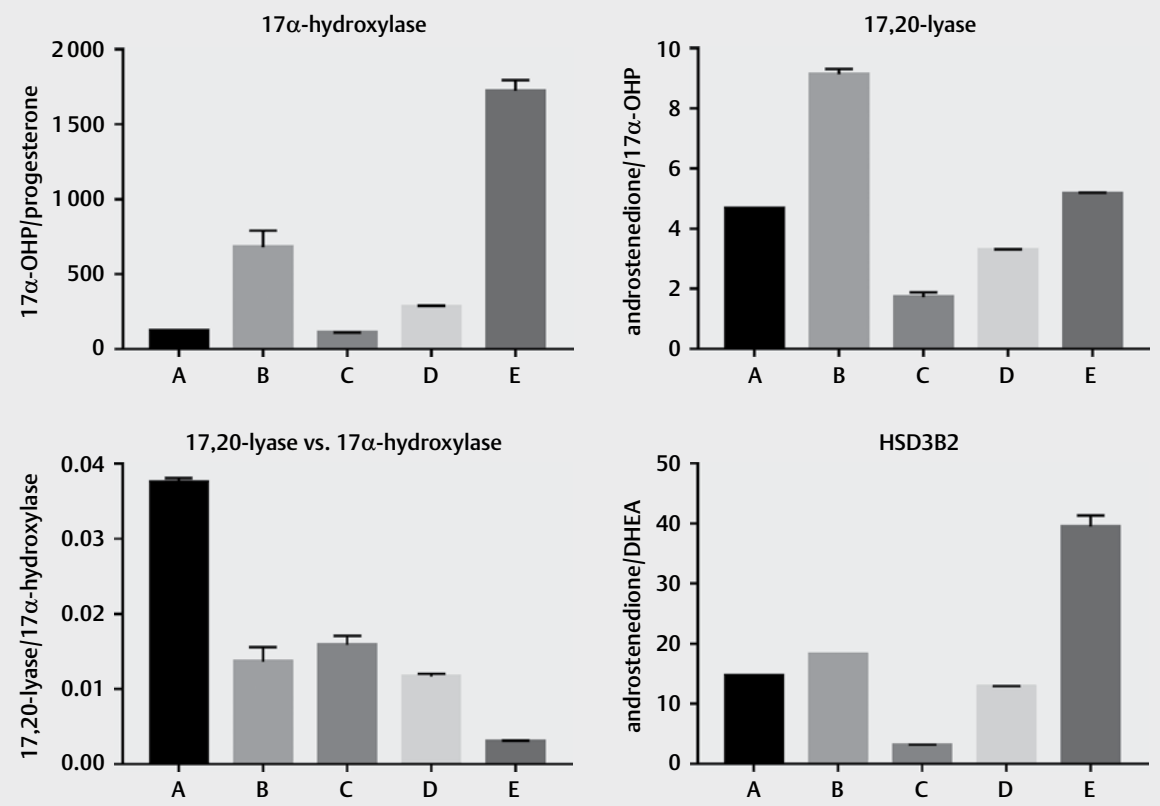

- Fig. 6 Diagnostic ratios of steroid concentrations in different cell lines (NCI-H295R cells purchased from CLS (cell lines A, B, C, E) or ATCC (D) reflecting enzyme activities of 3 $\beta$-hydroxysteroid-dehydrogenase (HSD3B2) and 17 $\alpha$-hydroxylase and 17, 20-lyase. Values are mean of biological duplicates.

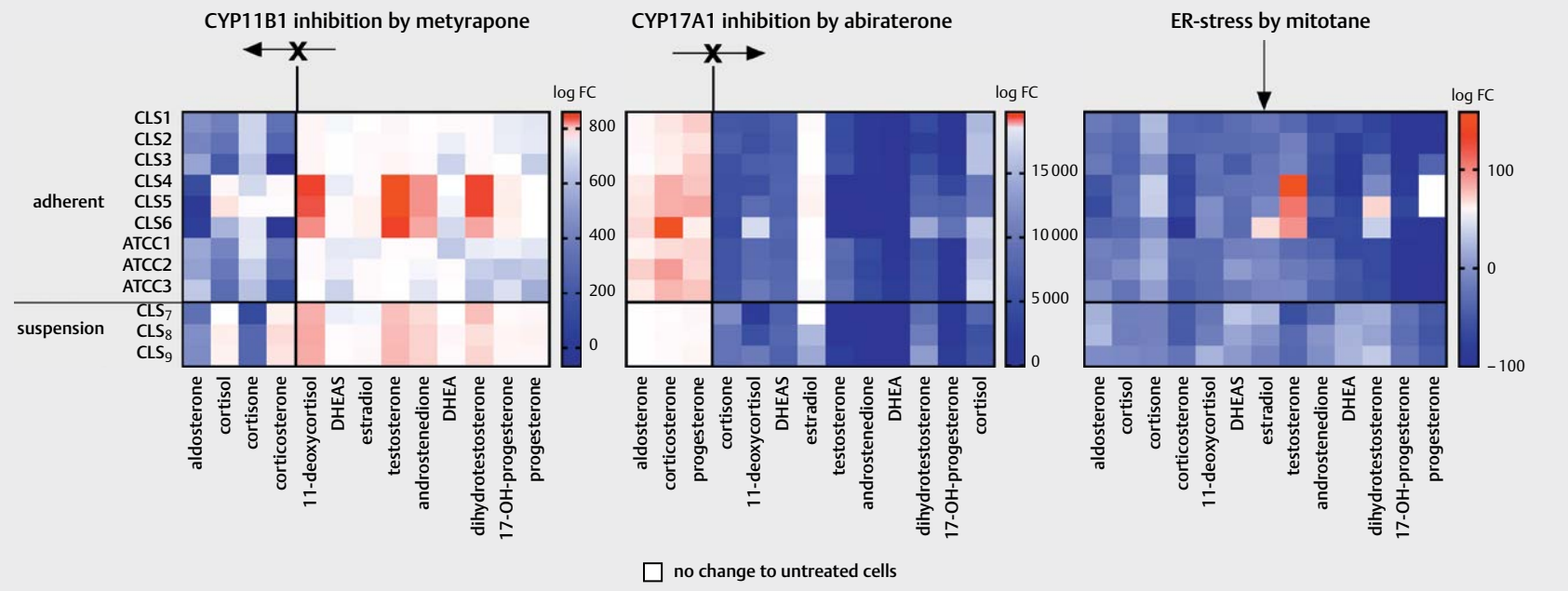

Fig. 7 Steroid pattern of various NCI-H295R (S) cell lines illustrate the heterogeneity in response to CYP 11 B1 (metyrapone) and CYP17A1 (abiraterone) inhibition and ER-stress, respectively induced by mitotane. Heat map analysis of LC-MS/MS data. The columns represent the measured steroids normalized on cell count and the rows the various $\mathrm{NCl}-\mathrm{H} 295$ cell lines and passages. Cells were exposed to metyrapone $(0.5 \mu \mathrm{M})$, abiraterone $(1 \mu \mathrm{M})$ and mitotane $(10 \mu \mathrm{M})$ for $48 \mathrm{~h}$. Values are mean of biological triplicates. FC (fold change)

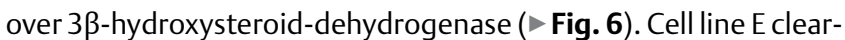
ly shows the highest $17 \alpha$-hydroxylase conversion (ratio $1722 \pm 73$ ) while the other CLS cells in general prefer the mineralocorticoid way via HSD3B2. The strong $17 \alpha$-hydroxylase activity of cell line $E$ is underlined by comparing $17 \alpha-\mathrm{OHP} /$ progesterone ratios which is lowest (ratio $108 \pm 2$ ) in cell line $C$. The most significant relative conversion activity via 17,20 lyase can be found in cell line B. By comparing diagnostic ratios of $17 \alpha$-hydroxylase and 17,20 lyase reac- tion rates, cell line $A$ dominates represented by ratio of $0.038 \pm 0.0005$.

\section{Manipulation of steroidogenesis with inhibitors}

Three consecutive early and late passages of NCl-H295R cells from cell line 0 , three passages of ATCC cells and $\mathrm{NCl}-\mathrm{H} 295$ suspension cells were treated with inhibitors of steroidogenesis ( $\mathbf{F i g}$. 7). The CYP11B1 inhibitor metyrapone led to a decrease of aldosterone, 
cortisol, cortisone and corticosterone, which was however not apparent in some adherent cells $\left(\mathrm{CLS}_{4}, \mathrm{CLS}_{5}, \mathrm{CLS}_{6}\right)$ and suspension cells $\left(\mathrm{CLS}_{7}, \mathrm{CLS}_{8}, \mathrm{CLS}_{9}\right)$ where cortisol and corticosterone remained almost unchanged. increase in 11-deoxycortisol, testosterone and dihydrotestosterone concentration was only observed in $\mathrm{CLS}_{4}, \mathrm{CLS}_{5}$ and $\mathrm{CLS}_{6}$ adherent cells and in suspension cells indicating an impact of passaging on steroidogenic properties.

Inhibition of CYP17A1 by abiraterone showed a consistent increase of aldosterone, corticosterone and progesterone while glucocorticoids and androgens decreased in all cell lines. In suspension cells aldosterone, corticosterone and progesterone production was almost unchanged. A massive decrease of all steroids was induced by mitotane reflecting the interference in early state of cholesterol metabolism and endoplasmic reticulum stress. In three passages of $\mathrm{CLS}\left(\mathrm{CLS}_{4}, \mathrm{CLS}_{5}\right.$ and $\left.\mathrm{CLS}_{6}\right)$ cells we found an increasing amount of testosterone compared to unexposed cells.

\section{Discussion}

Our experiments clearly show that secretion of steroids is influenced by the provider of $\mathrm{NCl}-\mathrm{H} 295$ cells, passaging and cell culture media. While prolonged passaging is known to change properties of cell lines, phenotypic consequences of media are less well understood.

Even though all cell lines investigated are based not only on the same original cells but also derive from the same substrain ( $\mathbf{F i g . 1}$ ) $\mathrm{NCl}-\mathrm{H} 295 \mathrm{R} \mathrm{S1}$, the extent of changes in steroidogenesis was striking.

In early experiments Gazdar et al. in 1990 already analyzed steroid secretion of $\mathrm{NCl}-\mathrm{H} 295$ cells by GC-MS and photometric methods [21] and found higher secretion of cortisol and androstenedione in medium containing $2 \%$ bovine serum which was similar with regard to most other steroids and consistent with an overall stimulation of steroidogenesis. Although the exact amount of steroids normalized to cell count is not exactly comparable, they found $0.5 \mu \mathrm{g} / 10^{6}$ cells cortisol, $0.4 \mu \mathrm{g} / 10^{6}$ cells androstenedione and $0.1 \mu \mathrm{g} / 10^{6}$ cells DHEA which is less than $10 \%$ of the quantity in our experiments. Despite heterogeneity, overall the complete spectrum of adrenal androgen and glucocorticoid pathways was expressed (CYP11A1, CYP17A1, CYP21A2, CYP11B2, CYP11B1) [22] which is in accordance with the results by Gazdar et al. [21] that were obtained 10 years after establishing the initial cell line.

Wang et al. compared aldosterone production among different human adrenocortical cell lines including $\mathrm{S} 1-3$ substrains of $\mathrm{NCl}$ $\mathrm{H} 295 \mathrm{R}$ cells [32] at the level of steroidogenesis and mRNA expression of key enzymes and showed CYP11A1, HSD3B2, CYP11B1 and CYP11B2 expression with remarkable difference between the $\$ 2$ and S3 substrains of $\mathrm{NCl}-\mathrm{H} 295 \mathrm{R}$ cells. These cell strains differ only in the adaption to cell culture medium composition ( $\triangleright$ Fig. 1).

In our hands, ATCC passage 16 cells exhibited a clear predominance of progesterone, $17 \alpha-\mathrm{OHP}$, androstenedione, DHEA, testosterone and DHT but also glucocorticoids in comparison to reference cell line (CLS, substrain 1, passage 21). This observation is consistent with data presented by Hornsby et al. [33] who showed a decline in CYP17A1 activity related to senescence. Hence it appears that the relative increase of aldosterone and corticosterone in CLS cells might reflect reduced $17 \alpha$-hydroxylase/lyase activity but also may impair overall steroid production. Ratios of marker substanc- es representing hydroxylase and lyase activities suggest a predominant pathway to androstenedione via 17-hydroxypregnenolone and DHEA. However, as pregnenolone and 17-hydroxypregnenolone were not included in our measurements, the approach provides only partial insight into the entire steroidogenic network.

We cannot explain all aspects of steroid hormone secretion without detailed enzyme expression data available. For example, relevant amounts of cortisone suggest the in vitro activity of $11 \beta$-hydroxysteroid dehydrogenase and 5 - $\alpha$ reductase appears to be active in some strains (A/D) as indicated [24] by considerable quantities of DHT. With the exception of DHEAS, our assay does not capture steroid hormone metabolites. Presence of sulfotransferases may explain the decline of some steroids such as estradiol over time in a subset of our experiments. Care should be taken in choosing cells reflecting best the targeted approach and research question.

Exposure of $\mathrm{NCl} \mathrm{H} 295$ cells from different origins to abiraterone, metyrapone and mitotane was consistent with the overall expected patterns that are explained by the respective mechanism of each drug. However, in early passage cell lines treatment with metyrapone e. g. did not lead to increased 11-deoxycortisol and androgen -secretion, which was the case in later passage cultures.

There are several possible explanations such as less active steroidogenesis in earlier passages leading to less pronounced accumulation of precursors and diversion to androgens or off target effects of inhibitors [34]. Since in the in vitro system used, feedback through corticotropin is absent and cAMP/PKA was not experimentally stimulated, increase in 11-deoxycortisol observed upon metyrapone incubation in some cell lines may indicate autonomous PKA activation in $\mathrm{NCl}-\mathrm{H} 295$ cells. The decrease in glucocorticoids and androgens and switch to mineralocorticoids in the presence of abiraterone suggests relevant inhibition of 17-alpha-hydroxylase (and not only 17,20-lyase). Consequences of abiraterone treatment in vivo are well known and include a rise of mineralocorticoids. However these in vivo results are not transferable to our experiments as stimulation through feedback mechanisms is absent [35] as described above. Recently, canine adrenal cells were tested as a model to study the impact of abiraterone on steroidogenesis [36]. In accordance with our results abiraterone treatment led to elevation of progesterone and decrease of $17 \alpha$-OHP, 11-deoxycortisol, cortisol, androstenedione and cortisone but in that system, also to reduced aldosterone and corticosterone production ( $>$ Fig. 7).

Finally mitotane blocked steroidogenesis pathway in $\mathrm{NCl}-\mathrm{H} 295$ cells at an early stage which resulted in decreased levels for nearly all steroids consistent with the recently described down-regulation of steroidogenesis by accumulation of free cholesterol through SOAT1 inhibition and subsequent blockage of sterol responsive genes. This appears to depend on both down-regulation of sterol-responsive element binding transcription factors and induction of endoplasmic reticulum stress [9]. Our results do not support a direct influence on steroidogenic enzymes similar to recent reports [37].

For decades, $\mathrm{NCl}-\mathrm{H} 295$ cells have been the only model for human adrenal physiology and the development of sub-strains enabled clarification of aspects related to mineralocorticoid, glucocorticoid and androgen synthesis. However the unavailability of alternative human cell line models has been a serious obstacle in ACC research since results could not be reproduced in other cellular contexts. 
- Table 1 practical recommendations for experiments using NCI-H295 cell lines focusing on steroidogenesis

\begin{tabular}{|l|l|}
\hline factor influencing sterodogenesis & consequence \\
\hline cell (sub)strain & careful selection of cell (substrain) use of the same (sub)strain whenever [possible \\
\hline passage & use of same/similar passage periodic measeurement of secretory activity. \\
\hline vendor & use the same source/vendor \\
\hline medium & $\begin{array}{l}\text { choose of medium depending on steroidognic pathway under study assessment of staroidogensis } \\
\text { preferably by LC-MS/MS when supplier/batch changes }\end{array}$ \\
\hline steroid hormone content of media & $\begin{array}{l}\text { use of the same medium whenever possible blank medium required for experiments assessing steroid } \\
\text { synthesis, normalization of results on initial quantity of hormones/steroids }\end{array}$ \\
\hline
\end{tabular}

Observed heterogeneity may be partly explained by evolutionary effects occurring in cultivated cell lines. Accordingly, Uri BenDavid et al. described extensive variation in response of 27 MCF7 cell strains to 321 different drugs which was related to gene expression and transcriptional pattern [31].

The landscape of human ACC cell line models is starting to change with the description of MUC-1 cells [19] and CU-ACC1 and 2 cells [20]. These reflect a broader range of the biological spectrum of ACC and will enable independent verification experiments. It is necessary to mention, however, the artificial upregulation of steroidogenesis e. $\mathrm{g}$. by addition of cholera toxin to the culture medium with the aim to increase cellular cAMP content. This may limit the utility of some cell lines for the study of adrenal physiology.

Moreover our study explains the partly divergent results obtained in the presumably identical cell line and uses steroids as surrogate markers of signaling cascades. It is generally acknowledged that prolonged passaging changes properties of cell lines but consequences of culture in different media are less well understood. Therefore our findings provide additional evidence that care must be applied when choosing culture conditions in particular since effects are often more difficult to assess compared to steroidogenesis. LC-MS/MS is an ideal tool to comprehensively characterize steroidogenesis and to ensure reproducibility. Our findings can be summarized in practical recommendations ( $\triangleright$ Table 1 ) for cell culture experiments focusing on steroidogenesis.

\section{Acknowledgments}

We thank Felix Beuschlein and Constanze Hantel, University Hospital Zürich, for providing $\mathrm{NCl}-\mathrm{H} 295$ cells included in this study and Sabine Herterich for STR-authentication of cell lines and strains. This manuscript has been presented as a poster at the $18^{\text {th }}$ Adrenal Cortex Conference held from June 25-27 in Munich and at the $60^{\text {th }}$ DGE Conference.

\section{Funding}

This work was supported in part by the Deutsche Forschungsgemeinschaft (DFG) within the CRC/TRR 205 "The adrenal, central relay in health and disease", project B16 to $\mathrm{MKr}$ and MF, the DFG grants KR4371/1-2 and FA 466/4-2 to MKr and MF, in addition by a short term fellowship of the European Society of Endocrinology to MKu.

\section{Conflict of Interest}

The authors declare that they have no conflict of interest.

\section{References}

[1] Golden SH, Robinson KA, Saldanha I et al. Clinical review: Prevalence and incidence of endocrine and metabolic disorders in the United States: A comprehensive review. J Clin Endocrinol Metab 2009; 94 : 1853-1878. doi: 10.1210/jc.2008-2291

[2] Kerkhofs TM, Verhoeven RH, Van der Zwan JM et al. Adrenocortical carcinoma: A population-based study on incidence and survival in the Netherlands since 1993. Eur J Cancer. 2013; doi: 10.1016/j. ejca.2013.02.034

[3] Fassnacht M, Kroiss M, Allolio B. Update in adrenocortical carcinoma. ] Clin Endocrinol Metab 2013; 98: 4551-4564. doi: 10.1210/jc.20133020

[4] Else T, Kim AC, Sabolch A et al. Adrenocortical carcinoma. Endocrine reviews 2014; 35: 282-326. doi: 10.1210/er.2013-1029

[5] Libe R, Borget I, Ronchi CL et al. Prognostic factors in stage III-IV adrenocortical carcinomas (ACC): An European Network for the Study of Adrenal Tumor (ENSAT) study. Annals of oncology: Official journal of the European Society for Medical Oncology / ESMO 2015; 26: 2119-2125. doi: $10.1093 /$ annonc/mdv329

[6] Poli G, Cantini G, Armignacco R et al. Metformin as a new anti-cancer drug in adrenocortical carcinoma. Oncotarget 2016; 7: 49636-49648. doi: 10.18632/oncotarget.10421

[7] LaPensee CR, Mann JE, Rainey WE et al. ATR-101, a Selective and Potent Inhibitor of Acyl-CoA Acyltransferase 1, Induces Apoptosis in H295R Adrenocortical Cells and in the Adrenal Cortex of Dogs. Endocrinology 2016; 157: 1775-1788. doi: 10.1210/en.2015-2052

[8] Kroiss M, Sbiera S, Kendl S et al. Drug Synergism of Proteasome Inhibitors and Mitotane by Complementary Activation of ER Stress in Adrenocortical Carcinoma Cells. Horm Cancer 2016; 7: (5-6) 345-355. doi: $10.1007 / \mathrm{s} 12672-016-0273-2$

[9] Sbiera S, Leich E, Liebisch G et al. Mitotane Inhibits Sterol-O-Acyl Transferase 1 Triggering Lipid-Mediated Endoplasmic Reticulum Stress and Apoptosis in Adrenocortical Carcinoma Cells. Endocrinology 2015; 156: 3895-3908. doi: 10.1210/en.2015-1367

[10] Germano A, Rapa I, Volante M et al. Cytotoxic activity of gemcitabine, alone or in combination with mitotane, in adrenocortical carcinoma cell lines. Molecular and cellular endocrinology 2014; 382: 1-7. doi: 10.1016/j.mce.2013.08.023

[11] Mariniello B, Rosato A, Zuccolotto G et al. Combination of sorafenib and everolimus impacts therapeutically on adrenocortical tumor models. Endocr Relat Cancer 2012; 19: 527-539. doi: 10.1530/ ERC-11-0337 
[12] Lafont ], Laurent $\mathrm{M}$, Thibout $\mathrm{H}$ et al. The expression of novH in adrenocortical cells is down-regulated by TGFbeta 1 through c-Jun in a Smad-independent manner. The Journal of biological chemistry 2002; 277: 41220-41229. doi: 10.1074/jbc.M204405200

[13] Brenner T, O'Shaughnessy KM. Both TASK-3 and TREK-1 two-pore loop K channels are expressed in $\mathrm{H} 295 \mathrm{R}$ cells and modulate their membrane potential and aldosterone secretion. American journal of physiology. Endocrinology and metabolism 2008; 295: E1480-E1486. doi: 10.1152/ ajpendo.90652.2008

[14] Ma Y, Han J, Guo Y et al. Disruption of endocrine function in in vitro $\mathrm{H} 295 \mathrm{R}$ cell-based and in in vivo assay in zebrafish by 2,4-dichlorophenol. Aquat Toxicol 2012; 106-107: 173-181. doi: 10.1016/j. aquatox.2011.11.006

[15] Karmaus AL, Toole CM, Filer DL et al. High-Throughput Screening of Chemical Effects on Steroidogenesis Using H295R Human Adrenocortical Carcinoma Cells. Toxicological sciences: An official journal of the Society of Toxicology 2016; 150: 323-332. doi: 10.1093/toxsci/ kfw002

[16] Gracia T, Hilscherova K, Jones PD et al. Modulation of steroidogenic gene expression and hormone production of H295R cells by pharmaceuticals and other environmentally active compounds. Toxicology and applied pharmacology 2007; 225: 142-153. doi: 10.1016/j.taap.2007.07.013

[17] Canton RF, Sanderson JT, Nijmeijer $S$ et al. In vitro effects of brominated flame retardants and metabolites on CYP17 catalytic activity: A novel mechanism of action? Toxicology and applied pharmacology 2006; 216: 274-281. doi: 10.1016/j.taap.2006.05.007

[18] Havelock JC, Auchus RJ, Rainey WE. The rise in adrenal androgen biosynthesis: Adrenarche. Semin Reprod Med 2004; 22: 337-347. doi: 10.1055/s-2004-861550

[19] Hantel C, Shapiro I, Poli G et al. Targeting heterogeneity of adrenocortical carcinoma: Evaluation and extension of preclinical tumor models to improve clinical translation. Oncotarget 2016; 7: 79292-79304. doi: 10.18632 /oncotarget.12685

[20] Kiseljak-Vassiliades K, Zhang Y, Bagby SM et al. Development of new preclinical models to advance adrenocortical carcinoma research. Endocr Relat Cancer 2018; 25: 437-451. doi: 10.1530/ERC-17-0447

[21] Gazdar AF, Oie HK, Shackleton CH et al. Establishment and characterization of a human adrenocortical carcinoma cell line that expresses multiple pathways of steroid biosynthesis. Cancer Res 1990; 50: 5488-5496

[22] Wang T, Rainey WE. Human adrenocortical carcinoma cell lines. Mol Cell Endocrinol 2012; 351: 58-65. doi: 10.1016/j.mce.2011.08.041

[23] Parmar ], Key RE, Rainey WE. Development of an adrenocorticotropinresponsive human adrenocortical carcinoma cell line. J Clin Endocrinol Metab 2008; 93: 4542-4546. doi: 10.1210/jc.2008-0903

[24] Rainey WE, Bird IM, Mason JI. The NCI-H295 cell line: a pluripotent model for human adrenocortical studies. Mol Cell Endocrinol 1994; 100: $45-50$

[25] Lichtenauer UD, Shapiro I, Osswald A et al. Characterization of $\mathrm{NCl}-\mathrm{H} 295 \mathrm{R}$ cells as an in vitro model of hyperaldosteronism. Horm Metab Res 2013; 45: 124-129. doi: 10.1055/s-0032-1323810
[26] Samandari E, Kempna P, Nuoffer JM et al. Human adrenal corticocarcinoma $\mathrm{NCl}-\mathrm{H} 295 \mathrm{R}$ cells produce more androgens than $\mathrm{NCl}-\mathrm{H} 295 \mathrm{~A}$ cells and differ in 3beta-hydroxysteroid dehydrogenase type 2 and 17,20 lyase activities. J Endocrinol 2007; 195: 459-472. doi: 10.1677/ JOE-07-0166

[27] Bird IM, Hanley NA, Word RA et al. Human NCI-H295 adrenocortical carcinoma cells: a model for angiotensin-II-responsive aldosterone secretion. Endocrinology 1993; 133: 1555-1561. doi: 10.1210/ endo.133.4.8404594

[28] Bird IM, Mason JI, Oka K et al. Angiotensin-II stimulates an increase in CAMP and expression of 17 alpha-hydroxylase cytochrome P450 in fetal bovine adrenocortical cells. Endocrinology 1993; 132: 932-934. doi: 10.1210/endo.132.2.8381079

[29] Rainey WE, Bird IM, Sawetawan C et al. Regulation of human adrenal carcinoma cell ( $\mathrm{NCl}-\mathrm{H} 295)$ production of $\mathrm{C} 19$ steroids. J Clin Endocrinol Metab 1993; 77: 731-737. doi: 10.1210/ jcem.77.3.8396576

[30] McAllister JM, Hornsby PJ. Dual regulation of 3 beta-hydroxysteroid dehydrogenase, 17 alpha-hydroxylase, and dehydroepiandrosterone sulfotransferase by adenosine 3',5'-monophosphate and activators of protein kinase $\mathrm{C}$ in cultured human adrenocortical cells. Endocrinology 1988; 122: 2012-2018. doi: 10.1210/endo-122-5-2012

[31] Ben-David U, Siranosian B, Ha G et al. Genetic and transcriptional evolution alters cancer cell line drug response. Nature 2018; 560: (7718) 325-330. doi: 10.1038/s41586-018-0409-3

[32] Wang T, Rowland JG, Parmar ] et al. Comparison of aldosterone production among human adrenocortical cell lines. Horm Metab Res 2012; 44: 245-250. doi: 10.1055/s-0031-1298019

[33] Hornsby PJ, Yang LQ. A model for phenotypic switching in adrenocortical cells senescing in culture. Mech Ageing Dev 1991; 58: 1-12

[34] Hilscherova K, Jones PD, Gracia T et al. Assessment of the effects of chemicals on the expression of ten steroidogenic genes in the H295R cell line using real-time PCR. Toxicol Sci 2004; 81: 78-89. doi: 10.1093/toxsci/kfh 191

[35] Pia A, Vignani F, Attard G et al. Strategies for managing ACTH dependent mineralocorticoid excess induced by abiraterone. Cancer Treat Rev 2013; 39: 966-973. doi: 10.1016/j.ctrv.2013.03.003

[36] Sanders K, de Wit WL, Mol JA et al. Abiraterone Acetate for Cushing's Syndrome: Study in a Canine Primary Adrenocortical Cell Culture Model. Endocrinology. 2018; doi: 10.1210/en.2018-00588

[37] Germano A, Saba L, De Francia S et al. CYP11B1 has no role in mitotane action and metabolism in adrenocortical carcinoma cells. PloS one 2018; 13: e0196931. doi: 10.1371/journal.pone.0196931

[38] Krone N, Hughes BA, Lavery GG et al. Gas chromatography/mass spectrometry (GC/MS) remains a pre-eminent discovery tool in clinical steroid investigations even in the era of fast liquid chromatography tandem mass spectrometry (LC/MS/MS). J Steroid Biochem Mol Biol 2010; 121: (3-5) 496-504. doi: 10.1016/j.jsbmb.2010.04.010 